\title{
First report of bacterial shallow bark canker of walnut (Juglans regia) caused by Brenneria nigrifluens in Turkey
}

\author{
Soner Soylu ${ }^{1} \cdot$ Merve Kara $^{1} \cdot$ İmam Adem Bozkurt ${ }^{1} \cdot$ Emine Mine Soylu $^{1} \cdot$ Şener Kurt ${ }^{1} \cdot$ Aysun Uysal $^{2}$
}

Received: 27 March 2020 / Accepted: 10 September 2020 / Published online: 14 September 2020

C) Società Italiana di Patologia Vegetale (S.I.Pa.V.) 2020

Keywords Brenneria nigrifluens $\cdot$ Walnut $\cdot$ Bark canker $\cdot$ Juglans regia $\cdot$ MALDI-TOF

During August 2019, vertical oozing cankers were sporadically observed on trunks and branches of local variety of English walnut (Juglans regia L.) trees in Hatay province of Turkey. Ten different bacterial isolates, having biochemical and physiological characters similar to those of Brenneria (formerly Erwinia) nigrifluens (Hauben et al. 1998), were obtained from naturally infected trees showing typical exudates and infected tissues, using King's B (KB) medium. Gram-negative, yellow non-fluorescent colonies were oxidase and HR on tobacco negative, did not hydrolyze gelatin and starch, and were positive for glucose, inositol, sorbitol, sucrose and arabinose. The identification of these isolates was further confirmed by matching reference $B$. nigrifluens isolate which is present in the library of MALDI-TOF. A pathogenicity test was performed on branches of 2-year-old walnut (cv. Chandler) saplings. Typical necrotic lesions were observed in the inner bark of inoculated branches three months after inoculation. Reisolates of $B$. nigrifluens were obtained from the margins of necrotic lesions on inoculated branches and identified as described above. The 16S rDNA, DNA gyrase subunit B ( gyrB) genes and specific oligonucleotides were amplified from DNA of re-isolates (WBb3a and WBn3b) with primer pairs of 27F/1492R, gyrB-Fps/gyrB-Rps (Sarkar and Guttman 2004), F1/C3 (Loretti et al. 2008) and sequenced. The sequences of 16S rDNA (GenBank accession Nos. MT07222 and MT072223), gyrB (MT750015) and F1/C3 (MT777240) were $98.2-100 \%$ similar to those of $B$. nigrifluens isolates including type strains from several hosts in multiple countries

Soner Soylu

soylu@mku.edu.tr

1 Department of Plant Protection, Hatay Mustafa Kemal University, Faculty of Agriculture, Hatay 31034, Turkey

2 Centre for Implementation and Research of Plant Health Clinic, Hatay Mustafa Kemal University, Hatay 31034, Turkey in the NCBI database (LR735983, LR735270, CP034036 for 16S, KC571240 for gyrB and EU178756 for F1/C3, respectively). On the basis of the symptoms, biochemical characteristics, pathogenicity test, MALDI-TOF and sequence analyses, the causal disease agent was identified as Brenneria nigrifluens. To our knowledge, this is the first report of the natural presence of bacterial shallow bark canker on walnut in Turkey.

\section{Compliance with ethical standards}

Conflict of interest The authors declares that there is no conflict of interest for this submission.

Research involving human participants and/or animals This article does not contain any studies with human participants or animals performed by any of the authors.

Informed consent This manuscript is new and not being considered elsewhere. The authors have read and approved the submission of this manuscript.

\section{References}

Hauben L, Moore ER, Vauterin L, Steenackers M, Mergaert J, Verdonck L, Swings J (1998) Phylogenetic position of phytopathogens within the Enterobacteriaceae. Appl Microbiol 21:384-397

Loretti S, De Simone D, Gallelli A (2008) Detection and identification of Brenneria nigrifluens, the causal agent of the shallow bark canker of walnut by, PCR amplification. J Phytopathol 156:464-469

Sarkar SF, Guttman DS (2004) Evolution of the core genome of Pseudomonas syringae, a highly clonal, endemic plant pathogen. Appl Environ Microbiol 70:1999-2012 